\title{
Modelling sustainability pathways: bridging science, policy and society
}

Article

Accepted Version

Lane, D. C. and Videira, N. (2019) Modelling sustainability pathways: bridging science, policy and society. Systems Research and Behavioral Science, 36 (2). pp. 147-155. ISSN 1099-1743 doi: https://doi.org/10.1002/sres.2586 Available at https://centaur.reading.ac.uk/82283/

It is advisable to refer to the publisher's version if you intend to cite from the work. See Guidance on citing.

To link to this article DOI: http://dx.doi.org/10.1002/sres.2586

Publisher: Wiley

All outputs in CentAUR are protected by Intellectual Property Rights law, including copyright law. Copyright and IPR is retained by the creators or other copyright holders. Terms and conditions for use of this material are defined in the End User Agreement.

\section{www.reading.ac.uk/centaur}

\section{CentAUR}

Central Archive at the University of Reading

Reading's research outputs online 


\title{
Guest Editorial
}

\section{Modelling Sustainability Pathways: Bridging science, policy and society}

\author{
David C Lane \& Nuno Videira
}

Correspondence to: Prof David C Lane, Henley Business School, Whiteknights, Reading, RG6 6UD, England.

\author{
E-mail: d.c.lane@henley.ac.uk
}

\section{Repository Note}

This document is the accepted version of the following article:

Lane DC and Videira N. 2019. Guest Editorial - Modelling Sustainability Pathways: Bridging science, policy and society: Selected papers from the Eighth European System Dynamics Workshop, at NOVA University Lisbon, Portugal. Systems Research and Behavioral Science 36: -. (2): to appear.

Note that the published version may have some differences from the version here. In all cases, the published version takes precedence.

If you wish to cite the ideas in this paper then please cite the version published in SR\&BS, NOT this version.

Please contact the Corresponding Author if you have any queries. 


\title{
Guest Editorial
}

\section{Modelling Sustainability Pathways: Bridging science, policy and society}

\author{
Selected papers from the Eighth \\ European System Dynamics Workshop, \\ at Universidade NOVA de Lisboa, Portugal
}

David C. Lane $^{1^{*}}$ and Nuno Videira ${ }^{2}$

1 Henley Business School, England

2 CENSE - Center for Environmental and Sustainability Research, NOVA School of Science and Technology, NOVA University Lisbon, Campus da Caparica, 2829-516 Caparica, Portugal

\section{INTRODUCTION}

System dynamics (SD) articles are now a frequent presence in this journal. This special issue contains a series of papers in that area. The creation of Jay Wright Forrester, SD is some six decades old (Forrester, 1958; 1961; 1968). In fact, its intellectual provenance goes back further, since the field can be seen to derive from a series of activities involving servomechanism theory, digital computing and aircraft simulators merged with the vivid and highly practical experiences of Forrester (Lane, 2007; 2010).

From a systems perspective it is clear that SD is firmly grounded in the holistic perspective, in the idea that this form of thinking provides a powerful way of engaging with the world, involving a range of stakeholders and uncovering actions which are effective. It is true that SD emerged from what has been called the 'servo-mechanism thread', in which interest falls on policies and continuous streams of information (Richardson, 1991). This stands in contrast with the more decision and event focus of many systems approaches, the work of Beer being perhaps the clearest example (Beer, 1959; 1966).

Along with its institutional and intellectual separation from MS/OR (Lane, 1994), SD was, for its first three decades, rather distant from the system sciences as generally conceived. However, connections began to appear. These came from outside SD, as system scientist interrogated SD, or tried to compare and contrast it with other approaches (e.g. Bloomfield, 1982; Jackson \& Keys, 1984; Keys, 1988). They also emerged from a small number of researchers at the heart of SD who chose to look outwards and place SD into a broader

\footnotetext{
* Correspondence to: Prof David C Lane FORS, Henley Business School, Whiteknights, Reading, RG6 6UD, England.

E-mail: d.c.lane@henley.ac.uk
} 
context (Richardson, 1991; Lane, 1994). This process has led to the creation of strong bonds, indeed, many would now consider SD to be firmly embedded in the modelling toolkit (Jackson, 2006; Government Office for Science, 2018), established as a star in the cosmology of systems science (Jackson, 2009) and engaging with affine areas - e.g. the 'behavioural turn'(Lane, 2017) or social theoretic roots (Checkland, 1981; Lane \& Husemann, 2008) - in a manner similar to other system science approaches.

This embedding can also be seen in this journal's support for the 'European System Dynamics Workshop' (EuSDW) series. These are bi-annual workshops held in a European location which consider a topic of interest to system dynamicists located in that generouslydefined geographical area. The most recent was held at Universidade NOVA de Lisboa in 2017. The various pieces in this issue derive from talks given there and they concern the modelling of issues associated with sustainability, the particular, trans-disciplinary approach adopted being indicated by the concern with science, policy and society.

\section{THE EUSDW WORKSHOP SERIES}

The Lisbon meeting joins a series of workshops. We now think of the very first European System Dynamics Workshop as the event hosted by Peter Milling and Andreas Größler in Mannheim in March 2003. So far the following EuSDWs have taken place:

\begin{tabular}{|c|c|c|}
\hline Date & Location & Theme \\
\hline 2003 & Universität Mannheim, Germany & $\begin{array}{l}\text { Rationality in System Dynamics: Modelling Human and } \\
\text { Organizational Decision Making }\end{array}$ \\
\hline 2005 & $\begin{array}{l}\text { Radboud Universiteit Nijmegen, } \\
\text { The Netherlands }\end{array}$ & $\begin{array}{l}\text { System Dynamics in Organizational Consultation: } \\
\text { Modelling for Intervening in Organizations }\end{array}$ \\
\hline 2007 & University of St. Gallen, Switzerland & Theory Building with System Dynamics \\
\hline 2009 & $\begin{array}{l}\text { Università degli Studi di Palermo, } \\
\text { Italy }\end{array}$ & $\begin{array}{l}\text { Public Sector Applications of the System Dynamics } \\
\text { Approach }\end{array}$ \\
\hline 2011 & $\begin{array}{l}\text { Frankfurt School of Finance \& } \\
\text { Management, Germany }\end{array}$ & $\begin{array}{l}\text { Developing Sustainable Strategies with System } \\
\text { Dynamics }\end{array}$ \\
\hline 2013 & Koç Üniversitesi, Istanbul, Turkey & $\begin{array}{l}\text { Health, Demographic Change, and Well-being: The } \\
\text { European Union's Horizon } 2020 \text { Program and System } \\
\text { dynamics }\end{array}$ \\
\hline 2015 & Universitetet i Bergen, Norway & $\begin{array}{l}\text { Natural Resource Management: Contributions of } \\
\text { System Dynamics to Research, Policy and } \\
\text { Implementation }\end{array}$ \\
\hline 2017 & $\begin{array}{l}\text { Universidade NOVA de Lisboa, } \\
\text { Portugal }\end{array}$ & $\begin{array}{l}\text { Modelling Sustainability Pathways: Bridging science, } \\
\text { policy and society }\end{array}$ \\
\hline
\end{tabular}

Each of these eight workshops has resulted in a special issue. For convenience, references to the associated special issues of SR\&BS may be found at the end of this Guest Editorial, via the citations Lane et al. (2004; 2006; 2008; 2010; 2012; 2015; 2017). 
The very first workshop provides the resilient and practical format all of for the subsequent meetings. We are very grateful to our hosts in Mannheim 16 years ago and shamelessly and happily follow the path that they set.
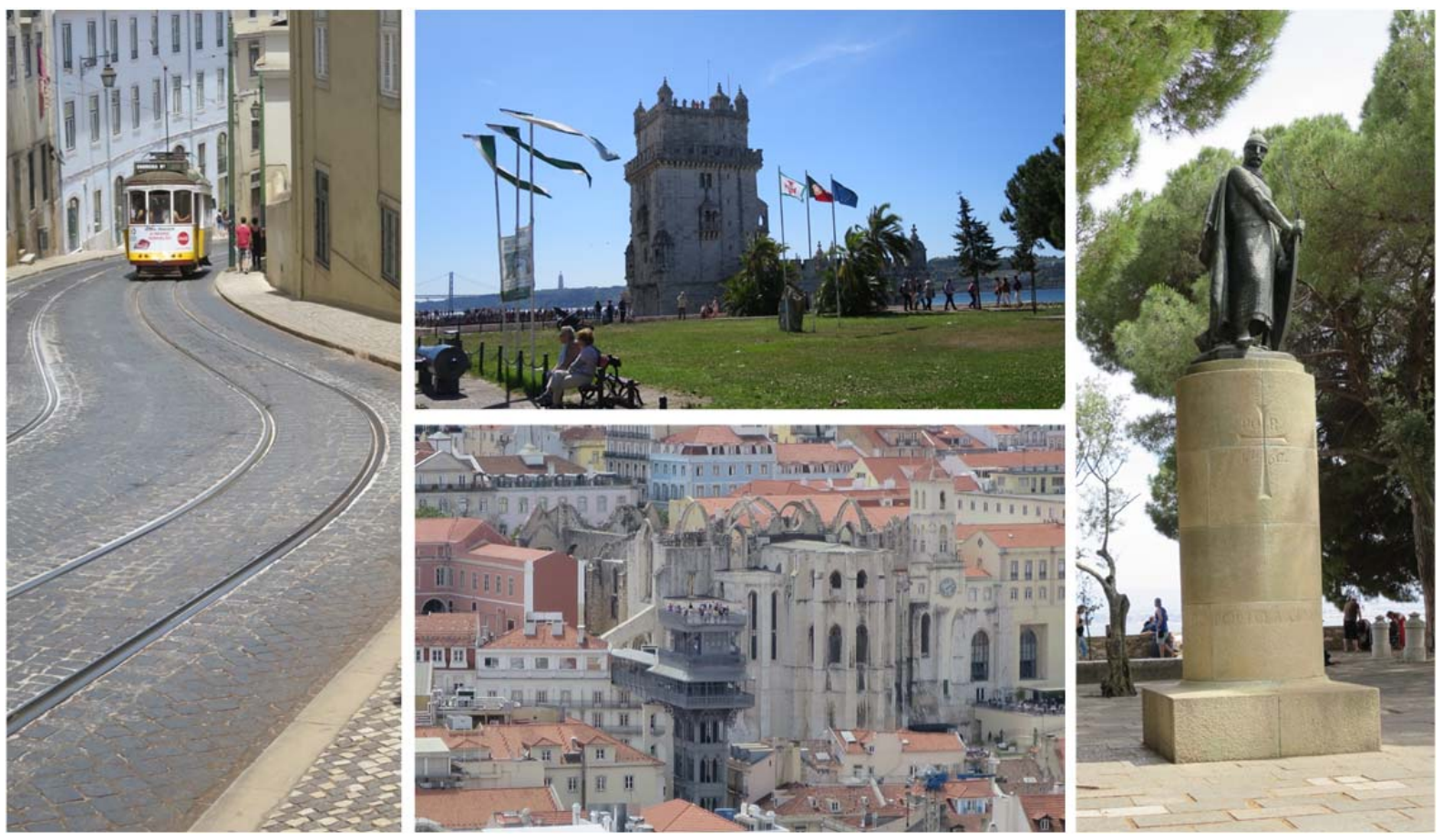

Figures 1: Facets of Lisbon (clockwise from top left): trams and hills; Torre de Belém (with part of the the Ponte 25 de Abril bridge at left); statue of hero of the Reconquista Martim Moniz in the Castelo de São Jorge; Elevador de Santa Justa. (All photographs available in colour online.)

\section{A WORKSHOP IN LISBON}

Lisbon, the capital city of Portugal, today has half a million inhabitants and sits on the Western (Atlantic) coast of the Iberian Peninsula, on the Tagus River. It is of the oldest capitals in Europe, older than Paris and London, with excavations revealing a Phoenician presence from around 1200 BCE. The name 'Lisbon' may be Proto-Celtic, or derived from pre-Roman names for the Tagus River, Lisso or Lucio.

Inhabited in Neolithic times by Pre-Celtic tribes, it was drawn into the orbit of the Roman Empire after the Second Punic War, eventually becoming part of the province of Lusitania and was an important trading city because of its large harbour in the river estuary. It was seized by Muslims in 711 and besieged and freed in 1147, this being a central point in the Reconquista. A key event in this was the death of Martim Moniz, who gave his life to hold open the gates of the city's castle, allowing Christian forces in. He is commemorated by a statue in the heart of the Castelo de São Jorge. (The siege itself is the subject - and metasubject - of José Saramago's 1989 novel 'História do Cerco de Lisboa'). In the 12th Century Lisbon became the capital of Portugal.

The city played a central role in various expeditions that made up the 'Age of Discovery', as European countries 'discovered' the extent of the world; at the close of the 15th Century, the voyage of Vasco de Gama departed from Lisbon and established a sea link to India. The city became a notable commercial centre. In its 'Golden Era' in the 16th Century it was a 
hub for goods from the Far East, Brazil and Africa, that trade involving spices, sugar, textiles and slaves. During this period the medieval Torre de Belém (Belém Tower), a small fortress which guards the entrance to the Tagus, was built, as well as the exquisite Mosteiro dos Jerónimos (Jerónimos Monastery). Today both are UNESCO World Heritage Sites.

The city has a history of earthquakes. That of 1755 is the most famous; it devastated the city and killed tens of thousands of inhabitants. It was the subject of notable literary and philosophical responses across Enlightenment Europe, from Voltaire to Kant. The rebuilding lead to the creation of two huge, elegant squares, the Praça do Rossio and the Praça do Comércio. In Lisbon today the Tagus is spanned by the Ponte Vasco da Gama and the Ponte 25 de Abril, both suspension bridges. The name of the latter commemorates the 1974 'Carnation Revolution' which lead - peacefully - to the removal of Portugal's military regime and the establishment of democracy.

Lisbon displays buildings and cultural influences from all of these eras. Visitors will also notice a curious interest in sardines and enjoy pastéis de nata, a Portugese type of egg custard tart which is very easy to find in Lisbon but very hard to stop eating (see also Bianchi, 2019). Standing proud in the city centre is the extraordinary Elevador de Santa Justa, a 1902 cast-iron lift and viewing platform which connects the high streets of Largo do Carmo with the lower streets of the Baixa district. Charming trams from the end of the 19th century glide through the streets, helping visitors ascend some of the more difficult hills; the view and the 'street scene' is always worth it. At the pinnacle of the city is Castelo de São Jorge, the Moorish castle from the 11th century with great, flowing walls which ring round, but also sometimes foray down the side of, the city's main hill. Views from here - indeed, from so many points in the city - are a delight.

Lisbon is a lovely and fascinating place which radiates a rich history and culture (see Figs. 1 \& 2).

Universidade NOVA de Lisboa was founded in 1973. The youngest of Lisbon's three state Universities, NOVA adopted since its inception a diversification model that integrates traditional academic domains together with novel interdisciplinary approaches and technological developments. According to its Statutes, as a public higher education institution, NOVA's mission is to serve society at the local, regional and global levels, advancing knowledge and understanding between cultures, societies and people. Through excellent teaching and research, as well as the provision of services based on a strong sense of community, NOVA has built a strong international profile characterised by collaborative research, solidarity and promotion of sustainable development, based on wide interinstitutional participation. Currently, NOVA has over 20000 enrolled students and 1800 teachers and researchers, across its nine schools and network of campuses (NOVA University Lisbon, 2019).

The NOVA School of Science and Technology (FCT NOVA) is located at the Caparica campus, municipality of Almada, across the river Tagus from Lisbon's city centre. FCT NOVA is one of the most prestigious Portuguese engineering and science public schools, organized in 14 departments and 16 research centres (FCT NOVA, 2019). The Department of Environmental Sciences and Engineering and CENSE - Centre for Environmental and Sustainability Research - were the academic and research units locally responsible for the EuSDW-VIII, organized by Nuno Videira, Paula Antunes, and Rui Ferreira dos Santos.

Universidade NOVA de Lisboa has been engaged in SD education since the mid-80's. SD was introduced in courses on the flagship Environmental Engineering masters programme at FCT NOVA and has remained a signature method underpinning thematic research lines and 
training initiatives in environmental systems analysis. Building on the extensive experience in SD applications to environmental and sustainability issues of CENSE researchers, NOVA joined the consortium of the Erasmus Mundus European Master in System Dynamics (EMSD) in 2011. The program has received an enthusiastic internal institutional support as well as external recognition by accreditation agencies. FCT NOVA offers three EMSD courses - Sustainability Science, Integrative Modelling and Sustainability Strategies Lab - which foster development of competences in the application of SD to sustainability issues, with a strong link to the research developed at CENSE.

CENSE is devoted to the pursuit of interdisciplinary research in environmental sciences and engineering, focusing on the interactions between human and ecological systems, to promote sustainable development (CENSE, 2019). One of the topics addressed by the Centre's Ecological Economics and Environmental Management (ECOMAN) research area is the development of a portfolio of analytical-deliberative approaches linking facts and stakeholder values (e.g., participatory system dynamics, multi-criteria analysis, scenarios, mixed-method approaches). Such approaches are increasingly called upon for tackling complexity in social-ecological systems. Dynamic complexity underpins 'wicked problems' (Rittel \& Webber, 1973) manifested in numerous environment and sustainability domains, such as protection of biodiversity and ecosystems services, water governance, sustainable consumption and post-growth development models. CENSE researchers work in close collaboration with society and policy organizations in the scope of international networks, participating as well in several EU and national R\&D projects.

Turning to the workshop itself, participants were invited to an informally reception the evening before on a hotel rooftop near Praça Martim Moniz in the city centre. Here they could gaze down at centuries' worth of architectural variety, stare out over the dazzling blue water of the Tagus, and look up to the Castelo de São Jorge. To reach the workshop itself involved travelling from the city south and across the impressive Ponte 25 de Abril (glancing west to the Belém Tower) and hence into the municipality of Almada, home of the Caparica campus of FCT NOVA, and into a lovely lecture theatre in the Library Building. The event proper began, involving speakers who had come from afar, local faculty and visitor and students in Lisbon for the EMSD (see Figs. 2 \& 3 and also Bianchi, 2019).

The workshop registered a total of 37 participants and sessions were held over a day and a half, on June 1-2, 2017. Paper presenters and discussants included Andreas Größler, Bent Bakken, Birgit Kopainsky, Carmine Bianchi, David Collste, David Lane, Enzo Bivona, Gabor Kiraly, José Luís Casanova, Jürgen Strohhecker, Krystyna Stave, Meike Tilebein, Paulo Gonçalves, Silvia Ulli-Beer, Steven Lade, Therese Bennich and Vincent de Gooyert.

The first day ended with many of the participants being guided by Krys Stave, a recurrent visiting scholar in the EMSD at FCT NOVA, to take a modern streetcar and then a ferry back across the water, watching the sunlight play in seemingly fractal patterns off the waves with the whole city laid out behind. 'Cap'n Krys' gathered around her a grateful and happy crew for this expedition. The evening involved a dinner at Lisbon's Bica district, a foray which involved using the swish underground metro system of the city and wandering through some of its oldest streets.

In a new element of the workshops, the second day began with a 'world café', in which EMSD Cohort 7 students - Alec Eckert, Amanda Karapici, Andres Zuna, Ekaterina Durova, Elena Shevyakova, Gian Wieck, Maral Kabbassova, Olga Poletaeva, Sergio Alzate and Teun Sluijs - discussed their Sustainability Strategies Lab course projects with workshop attendees, seeking constructive comment but also conveying their enthusiasm for SD (see 
Figs. 3). Group projects addressed topics related with policies proposed by the Portuguese Green Growth Commitment, including energy and climate, local lodging and urban rehabilitation, air pollution and traffic congestion, and waste management. This new feature was very popular. After further papers and discussion participants offered their thanks to the organisers and left the campus, their regret at the end of the scholarly component ameliorated by the chance to spend a little time exploring further the lovely city that was their host before returning home.
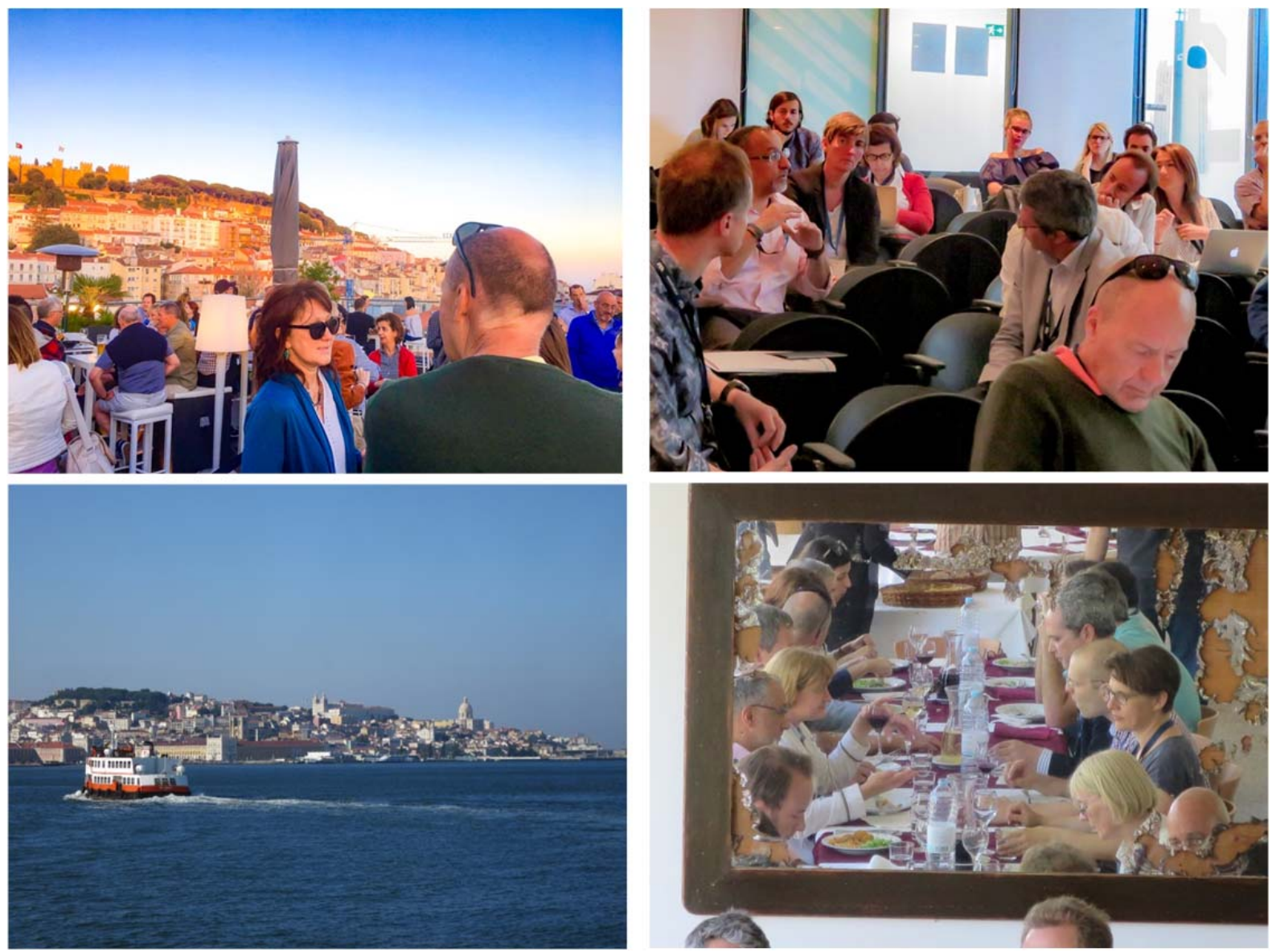

Figures 2. Participants at EuSDW-VIII in Lisbon (clockwise from top left): informal reception atop Hotel Mundial (Castelo de São Jorge top left); in-session debates; still talking at lunch; the city viewed during the return water crossing at the end of Day 1. (Photograph upper right by local organizing team.)

The Lisbon workshop used the general model of the series. Invited authors first gave a talk on their research project or topic, these having been invited on the basis that they contributed to the broader theme of the workshop, their papers having been circulated to invitees some weeks previously. A designated Discussant then responded with remarks to critique, support, or add further perspective. In open session, all participants then posed questions and contributed comments. A total of eight talk-pairs were given in this way.

Each of the workshops in the series is designed with its own specific aims in mind and this was no less true of EuSDW-VIII. Nevertheless, the guest editors are able to include in this 
special issue a selection of the ideas and projects discussed at EuSDW-VIII in the form of research papers. These were developed further, in part in response to comments from all workshop participants, and also as a result of the journal's refereeing processes. Also presented here are papers by the respective workshop 'discussants', providing a sense of the interplay of ideas at the event itself but offering journal readers alternative perspectives on the papers.
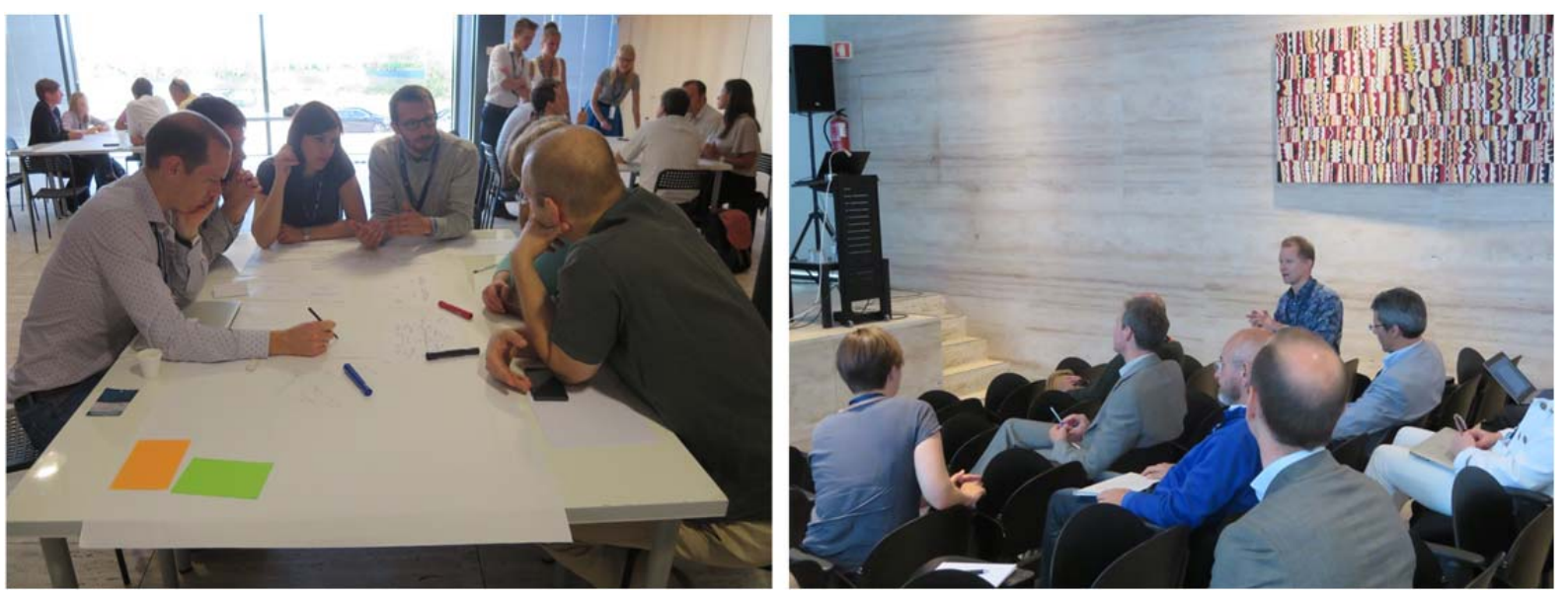

Figures 3. Participants at EUSDW-VIII in Lisbon: on Day 2 EMSD students discuss their research projects with other workshop attendees at the World café (left); work continues in session (right). (Both photographs by local organizing team.) For more images from the workshop see Bianchi (2019).

\section{MODELLING SUSTAINABILITY PATHWAYS}

The topic of the 2017 European System Dynamics Workshop was 'Modelling Sustainability Pathways: Bridging science, policy and society'. The sustainability concept has been channelling individual and collective visions to redesign the world in which we live and act. In Ehrenfeld's words, sustainability conveys the "possibility that humans and other life will flourish on the Earth forever" (Ehrenfeld, 2008, p6). This was visually represented in Raworth's doughnut (2012) by a safe and just space for humanity, bounded by an upper ceiling of environmental limits and a lower foundation of basic social needs. Designing the pathways of change steering individuals and organisations toward this sustainable operating space requires powerful modelling tools to support a better understanding of the dynamic complexity in social-ecological systems. To facilitate such transitions, the involvement of broad groups of scientists, policy-makers and other societal actors is increasingly advocated. Numerous researchers have argued that we need meaningful systems thinking capabilities to tackle complexity so that we can learn collectively. Hence, participatory modelling approaches play a role in the development of sustainability pathways by extending the sources of knowledge and fostering collaborative setting of rules for action.

Drawing from critical ecological economics and sustainability science frameworks, ECOMAN researchers at CENSE collaborate since the late $90^{\prime}$ 's in the development of participatory SD approaches to promote engagement of inter-organizational stakeholder groups in problem scoping and policy analysis processes. Highlights from the group's work on participatory SD related topics include: (i) development of systems mapping approaches (e.g. Videira et al., 
2012) and integrated sustainability assessment frameworks (e.g. Videira et al. 2010); (ii) mixed-method approaches combining participatory modelling with other assessment tools (e.g. Antunes et al., 2006; Videira et al. 2014; Herrera et al. 2016; Meinherz and Videira, 2018); (iii) applications to several environmental and sustainability themes, such as water governance (e.g. Videira et al., 2009; Antunes et al. 2009), ecosystem services (e.g. Lopes and Videira, 2017) and sustainable consumption (e.g. Sedlacko et al. 2014); and (iv) stocktaking of contributions to research methods and applications in environmental and sustainability studies (e.g. Antunes et al., 2015; Videira et al. 2011; Videira et al. 2017).

To further explore the role of participatory SD in sustainability dialogues, the EuSDW-VIII launched three research challenges which clustered workshop presentations and discussions: (iii) How to advance modelling of sustainability pathways with participatory SD?, (ii) How does SD support modelling of policies sustaining human systems above the minimum social foundations of Raworth's doughnut?, and (iii) How do SD modelling frameworks support understanding of earth system's dynamics and the safe operating space within planetary boundaries? In addressing these challenges, strong science-policy-society interfaces are increasingly needed to promote transitions toward sustainability. Within this context, SD plays a crucial role in the identification of leverage points, as well as in the facilitation of stakeholder co-creation processes for the design and implementation of model-based policies.

\section{CONTENTS OF THE SPECIAL ISSUE}

Presented here is a range of pieces concerning the workshop's main topic. The key features are the Research Papers but each of these has a Discussant's Comment which aims to add to the coverage of the topic. The special issue therefore proceeds as follows:

1. The issue opens with 'Exploring the value of participatory system dynamics in two paired field studies of stakeholder engagement in sustainability discussions' by Krystyna Stave, Michael Dwyer and Marcia Turner. They report two case studies of group model building using SD, their analysis of the cases supporting the view that participatory SD can contribute to improving stakeholder engagement processes. The Discussant's Comments that follow are by Andreas Größler who further elaborates on the trade-offs between effective and efficient approaches to participatory SD.

2. This is followed by a Research Paper by Bent E. Bakken. In 'Energy Transition Dynamics: Does Participatory Modelling Contribute to Alignment among Differing Future Worldviews?' he also considers an example of group model building but offers a rather more complex view of the effects of this approach. The Discussant's Comments by Silvia Ulli-Beer offers her view on the literature that explores the inherent complexities of attempts to align paradigms concerning futures states of a socio-technical transition.

3. The third paper is 'Dynamics of Participation: System Dynamics and Participation - An Empirical Review' by Gábor Király and Péter Miskolczi. The authors consider participative approaches through a sociological lens, considering how - particularly in the case of public policy decisions - it can lead to the empowerment of communities. José Luís Casanova provides Discussant's Comments which relate the contribution to a number of schools of thought from sociology. 
4. The fourth Research Paper comes from Birgit Kopainsky, Andreas Gerber, David LaraArango and Progress Nyanga and is called 'Short-term versus long-term decision tradeoffs: Evidence from a model-based observational experiment with African small-scale farmers'. The authors report a semi-computerized observational experiment in Zambia concerning conflicting production objectives and argue that modeling can contribute to decision makers' seeing the importance of a longer-term perspective. Jürgen Strohhecker's Discussant's Comments relates the findings to the emerging area of 'Behavioural System Dynamics'.

5. The final contribution builds on a Discussant's Comment from the workshop, though the original paper could not be included here. In 'New Truths Begin As Heresies: First thoughts on system dynamics and global modelling', David Lane contemplates the particular features of modelling in the domain addressed by this journal special issue and reflects particularly on the experiences then and now of two high profile SD contributions to it; 'World Dynamics' and 'The Limits To Growth'.

6. An Afterword by Carmine Bianchi offers some further thoughts on the workshop theme and some personal reflections on (and further photographs from) the 2017 meeting itself.

As guest editors we hope that this collection will be of interest to researchers and practitioners in System Dynamics, Systems Science, sustainability science, OR/MS, and all others interested in understanding complex dynamic systems.

\section{ACKNOWLEDGEMENTS}

In our role as guest editors we would like to offer our thanks to everyone who made this special edition possible:-

All those who organised the 2017 EuSDW-VIII workshop and who ensured that it ran so well, in particular Paula Antunes, Rui Ferreira dos Santos, Rita Lopes and Patrícia Tourais.

Support from NOVA School of Science and Technology and CENSE is acknowledged. CENSE is supported by the Portuguese Foundation for Science and Technology through the strategic project UID/AMB/04085/2013.

We also thank the consortium of the European Master in System Dynamics and the enthusiasm of all Cohort 7 students, particularly in the World Café session.

The referees for this special edition. When finding anonymous referees the Guest Editors drew on the global communities of systems scientists, operational researchers and system dynamicists; their contribution to the issue was vital.

Lesley Fitton of the Department of Greek and Roman Antiquities, and Janet Larkin of the Department of Coin and Medals, both of the British Museum, London, who provided the image from which the symbol used for the workshop series was derived. The owl is taken from the reverse side of a silver tetradrachm made in Athens around 480 BC. CM 1906-11-32591. Copyright British Museum, London. The symbol for the series of European System Dynamics Workshops was created by David Lane.

Finally, Amanda Gregory and Mike Jackson for inviting us to guest edit this special issue but also for their steadfast support for the European System Dynamics workshops. 


\section{References}

Antunes P, Santos R, Videira N. 2006. Participatory Decision Making for Sustainable Development - The Use of Mediated Modeling Techniques. Land Use Policy, 23, 4452.

Antunes P, Kallis G, Videira N, Santos R. 2009. Participation and evaluation for sustainable river basin governance. Ecological Economics, 68, 4, 931-939.

Antunes P, Stave K, Videira N, Santos R. 2015. Using participatory system dynamics in environmental and sustainability dialogues. Different modes for different purposes, in Ruth, M., (Ed.). Handbook of Research Methods and Applications in Environmental Studies, Edward Elgar, 346-374. ISBN: 9781783474639

Beer S. 1959. Cybernetics and Management. London: English Universities Press.

Beer S. 1966. Decision and Control: the meaning of operational research and management cybernetics. Wiley: Chichester.

Bianchi C. 2019. Afterword - Reflections on the 8th European System Dynamics Workshop. Systems Research and Behavioral Science 36: (*this issue*).

Bloomfield B. 1982. Cosmology, Knowledge and Social Structure: The case of Forrester and system dynamics. Journal of Applied Systems Analysis 9: 3-15.

CENSE 2019. About CENSE. CENSE - Center for Environmental and Sustainability Research, available at https://www.cense.fct.unl.pt/

Checkland PB. 1981. Systems Thinking, Systems Practice. Wiley: Chichester.

Ehrenfeld J. 2008. Sustainability by Design: A Subversive Strategy for Transforming Our Consumer Culture. Yale University Press: New Haven, USA.

FCT NOVA 2019. About FCT - Overview. FCT NOVA School of Science and Technology, available at https://www.fct.unl.pt/en/about-fct/

Forrester JW. 1958. Industrial Dynamics: A major breakthrough for decision makers. Harvard Business Review 36: 37-66.

Forrester JW. 1961. Industrial Dynamics. MIT Press: Cambridge, MA.

Forrester JW. 1968. Principles of Systems. MIT Press: Cambridge, MA.

Government Office for Science. 2018. Computational Modelling: Technological Futures (authors: Walport, M., Calder, M., Craig, C., Culley, D., de Cani, R., Donnelly, C., Douglas, R., Edmonds, B., Gascoigne, J., Gilbert, N. Hargrove, C., Hinds, D., Lane, D. C., Mitchell, D., Robertson, D., Rosewell, B., Sherwin. S., Wilson, A.). www.gov.uk/government/publications/computational-modelling-blackett-review: Available from.

Herrera H, McCardle-Keurentjes M, Videira N. 2016. Evaluating Facilitated Modelling Processes and Outcomes: An Experiment Comparing a Single and a Multimethod Approach in Group Model Building. Group Decision and Negotiation, 25 (6), 12771318.

Jackson MC. 2009. Fifty Years of Systems Thinking for Management. Journal of the Operational Research Society 60: s24-s32.

Jackson MC and Keys P. 1984. Towards a system of system methodologies. Journal of the Operational Research Society 35: 473-486.

Jackson MCD-. 2006. Beyond Problem Structuring Methods: Reinventing the Future of OR/MS. The Journal of the Operational Research Society 57: 868-878.

Keys P. 1988. System Dynamics: A methodological perspective. Transactions of the Institute of Measurement and Control 10: 218-224. 
Lane DC. 1994. With A Little Help From Our Friends: How system dynamics and 'soft' OR can learn from each other. System Dynamics Review 10: 101-134.

Lane DC. 2007. The Power of the Bond Between Cause and Effect: Jay Wright Forrester and the field of system dynamics. System Dynamics Review 23: 95-118.

Lane DC. 2010. High Leverage Interventions: Three cases of defensive action and their lessons for OR/MS today. Operations Research 58: 1535-1547.

Lane DC. 2017. 'Behavioural System Dynamics': A very tentative and slightly sceptical map of the territory. Systems Research and Behavioral Science 34: 414-423.

Lane DC and Husemann E. 2008. Steering without Circe: Attending to reinforcing loops in social systems (2007 Jay Wright Forrester Award address). System Dynamics Review 24: 37-61.

Lane DC and Schwaninger M (eds.). 2008. Theory Building with System Dynamics (Selected papers from the third European system dynamics workshop, University of St. Gallen, Switzerland). 25(4): Special Edition of the international journal Systems Research and Behavioral Science.

Lane DC and Kopainsky B (eds.). 2017. Natural Resource Management: Contributions of System Dynamics to Research, Policy and Implementation: Selected papers from the Seventh European System Dynamics Workshop, at Bergen University, Norway. 34(4): Special Edition of the international journal Systems Research and Behavioral Science.

Lane DC, Größler A and Milling PM (eds.). 2004. Rationality in System Dynamics: Selected papers from the first European system dynamics workshop, Mannheim University. 21(4): Special Edition of the international journal Systems Research and Behavioral Science.

Lane DC, Rouwette EAJA and Vennix JAM (eds.). 2006. System Dynamics in Organizational Consultation: Modelling for Interventions in Organizations (Selected papers from the second European system dynamics workshop, Radboud University Nijmegen). 23(4): Special Edition of the international journal Systems Research and Behavioral Science.

Lane DC, Bianchi C and Bivona E (eds.). 2010. Public Sector Applications of the System Dynamics Approach: Selected papers from the fourth European system dynamics workshop, at University of Palermo, Italy. 27(4): Special Edition of the international journal Systems Research and Behavioral Science.

Lane DC, Strohhecker J and Größler A (eds.). 2012. Developing Sustainable Strategies with System Dynamics: Selected papers from the fifth European system dynamics workshop, Frankfurt School of Finance \& Management, Germany. 29(6): Special Edition of the international journal Systems Research and Behavioral Science.

Lane DC, Pala O and Barlas Y (eds.). 2015. Health, Demographic Change, and Well-being: The European Union's Horizon 2020 Program and System dynamics: Selected papers from the Sixth European System Dynamics Workshop, at Koç University, Istanbul, Turkey. 32(4): Special Edition of the international journal Systems Research and Behavioral Science.

Lopes R, Videira N. 2017. Modelling feedback processes underpinning management of ecosystem services: The role of participatory systems mapping. Ecosystem Services, 28 Part A: 28-42.

Meinherz F, Videira N. 2018. Integrating qualitative and quantitative methods in participatory modelling to elicit behavioural drivers in environmental dilemmas: The case of air pollution in Talca, Chile. Environmental Management, 62:260-276. 
NOVA University Lisbon 2019. A Pioneer History; Mission and Strategic Plan. NOVA University Lisbon, available at https://www.unl.pt/en/nova/.

Raworth K. 2012. A Safe and Just Space for Humanity: Can We Live Within the Doughnut? Oxfam Discussion Papers, Oxford, UK.

Richardson GP. 1991. Feedback Thought in Social Science and Systems Theory. Univ. Pennsylvania: Philadelphia.

Sedlacko M, Martinuzzi A, Røpke I, Videira N, Antunes P. 2014. Participatory systems mapping for sustainable consumption: Discussion of a method promoting systemic insights. Ecological Economics, 106, 33- 43.

Rittel HWJ and Webber MM. 1973. Dilemmas in a general theory of planning. Policy Sciences 4: $155-169$.

Videira N, Antunes P, Santos R. 2009. Scoping river basin management issues with participatory modelling: The Baixo Guadiana experience. Ecological Economics, 68, 4, 965-978.

Videira N, Antunes P, Santos R, Lopes R. 2010. A Participatory Modelling Approach to Support Integrated Sustainability Assessment Processes. Systems Research and Behavioral Science, 27(4), 446-460.

Videira N, van den Belt M, Antunes P, Santos R, Boumans R. 2011. Integrated Modeling of Coastal and Estuarine Ecosystem Services. In: van den Belt M. and Costanza R. (Eds.) Vol. 12, Ecological Economics of Estuaries and Coasts. In Wolanski E. and McLusky D.S. (Eds.) Treatise on Estuarine and Coastal Science. Waltham, MA: Academic Press. ISBN: 978-0-12-374711-2.

Videira N, Lopes R, Antunes P, Santos R. 2012. Mapping Maritime Sustainability Issues with Stakeholder Groups. Systems Research and Behavioral Science, 29 (6), 596-619.

Videira N, Schneider F, Sekulova F, Kallis G. 2014. Improving understanding on degrowth pathways: An exploratory study using collaborative causal models. Futures, 55 (2014), 58-77.

Videira N, Antunes P, Santos R. 2017. Participatory Modelling in Ecological Economics: Lessons from Practice, in Spash (Ed.) Routledge Handbook of Ecological Economics: Nature and Society, Chapter 35, Routledge. ISBN: 978-1-13-893151-0 